\title{
Labour Migration in South East Asia: A Case Study of Malaysia (2000-2015)
}

\author{
Babul Hossain ${ }^{1 *}$, Saugata Kundu ${ }^{2}$ \\ ${ }^{1}$ Masters in population studies from International Institute of Population Sciences, Mumbai \\ ${ }^{2}$ Assistant teacher at Lakshmipur Michhutola Jr. Basic School, Malda, (West Bengal
}

*Corresponding Author: Babul Hossain, Masters in population studies from International Institute of Population Sciences, Mumbai

\begin{abstract}
Background: Cross border movement of the labour or labour migration has become a worldwide phenomenon. In terms of labour stock and flow, South East Asia is one of the key players in the world. Although within countries in this region, the labour migration pattern is very much diverse. Asian Financial Crisis of 1997 had hit hard the economy of this region [2]. It had also influenced the labour migration pattern of countries within this region. Economy, it did affect the labour migration but whether spatial interaction still plays any role in the flow of labour? In other hand which sectors are absorbing those migrant labours is needed to be address in the current situation. To examine these aspects this paper deals with immigration taking of Malaysia as an case study in post crisis period (after 2000).
\end{abstract}

Method: The paper is based on secondary data source. The data is collected from International Labour Organization (ILO) from 2000 to 2015. For the analysis of the level of spatial interaction geographical proximity has taken as variable and the Gravity Model has been used. The concentration of migrate workers to total working population has been measured by Location Quotient (LQ).

Result: Theoretically Myanmar, Philippines supposed to have low spatial interaction but they are the contributing high labour force in Malaysia whereas Thailand supposed to have high spatial interaction and high contribution of the labour force in the Malaysia but actual contribution is low for Thailand. In other hand Indonesia contribute maximum labour force in the Malaysia job market. Most of the migrant workers are concentrated in the industrial and agricultural sector and lowest contribution in the service sector.

Conclusion: Geographical proximity is important factor for labour migration but policy, economic condition of the origin country directly influence the labour migration. This is clear from Malaysia. As Myanmar or Philippines economic condition is less developed so high inflow of worker from these countries to Malaysia takes place. Whereas due to high involvement in service sector by native Malaysian workers, a vacuum in the agricultural and industrial sector has created that is supplemented by the migrant workers.

Keywords: Labour migration, Malaysian labour force, Gravity model, Concentration of migrant worker

\section{BACK GROUND}

Cross border movement of the labour or labour migration has become a worldwide phenomenon. In terms of labour stock and flow, South East Asia is one of the key players in the world and within South East Asian counties, international labour migration is prominent. Although within countries in this region, the labour migration pattern is very much diverse [1]. Asian Financial Crisis of 1997 had hit hard the economy of this region [2]. It had also influenced the labour migration pattern of countries within this region. Economy, it did affect the labour migration but whether spatial interaction still plays any role in the flow of labour? In other hand which sectors are absorbing those migrant labours is needed to be address in the current situation. To examine these aspects this paper deals with immigration trend of Malaysia in post crisis period (after 2000). In south-east Asia, Malaysia is one of the major migrant labour absorbing countries. As per 2014 ILO report, Malaysia has 1.8 million migrant workers representing total $13 \%$ of labour force of the country. The country is also unique in terms of its geographical location as part of it belongs to peninsula and parts of it an island South China Sea. 


\section{MATERIAL AND MeTHOD}

\subsection{Data Source}

The paper is based on secondary data source. The data is collected from International Labour Organization (ILO) from 2000 to 2015. Other population related data is collected from census reports of specific countries. The definition and other policy related data are collected from different journals and reports.

\subsection{Analysis Tools}

The study focuses on the labour immigration and spatial interaction relation and the concentration of migrant labours in different economic sectors. For the spatial interaction examination geographical proximity has taken as variable and the Gravity Model has been used. The formula for the gravity model is:Mij= $\mathrm{Pi} * \mathrm{Pj} / \mathrm{Dij}$

Where,

Mij= gravity model prediction of migration between origin and destination

$\mathrm{Pi}=$ population of origin of migration

$\mathrm{Pj}=$ population of origin of migration

$\mathrm{Dij}=$ distance between the origin and destination

The gravity model proves that spatial interaction is directly proportion to total population between two place and inversely proportion to the distance. Here this method used to predict level of migration between the countries.

The concentration of migrate workers to total working population has been measured by Location Quotient (LQ). It is calculated sector wise.

The formula is: $\mathrm{LQ}=(\mathrm{Mi} / \mathrm{Mj}) /(\mathrm{Ti} / \mathrm{Tj})$

Where,

$\mathrm{Mi}=$ migrate workers in a particular sector

$\mathrm{Mj}=$ total migrate worker

$\mathrm{Ti}=$ workers (migrate and native) in a particular sector

$\mathrm{T} j=$ total workers (migrate and native) in the country

Gravity model, given by Zief in1946 is used here. He used this model to provide a theoretical motivation for movement between cities.

The method location quotient (LQ) is developed by the American economist Robert Murray Haig in 1928 for his work on the Regional planning of New York.

\section{RESULT}

\subsection{Analysis of the Importance of Spatial Interaction as Factor of Labour Migration and Other Influencing Factors}

The figure1 shows that for Myanmar the value is 1in 2000 and also unchangeable 2010. In 2013 the value was 2. In the case of Philippines the value is also 1.23 in 2000, 1.79 in $2010 \& 1.98$ in 2013. It represent that there should be low spatial interaction of Malaysia with these countries. It can be predicted that there should be low migration take place with these countries. In other hand Thailand is important country by the value of the gravity model. Compare with other two countries the gravity value of Thailand is 3-4time higher than Myanmar, 2-3 times higher than Philippines. That means there should much higher probability of labour flow from Thailand to Malaysia. Indonesia has high proportion of the spatial interaction and that means there should be higher level of migration between Malaysia and Indonesia In 2000, the value was 5.47, in 2010 it was 7.61 time \& in 2013 it was 8.31. 


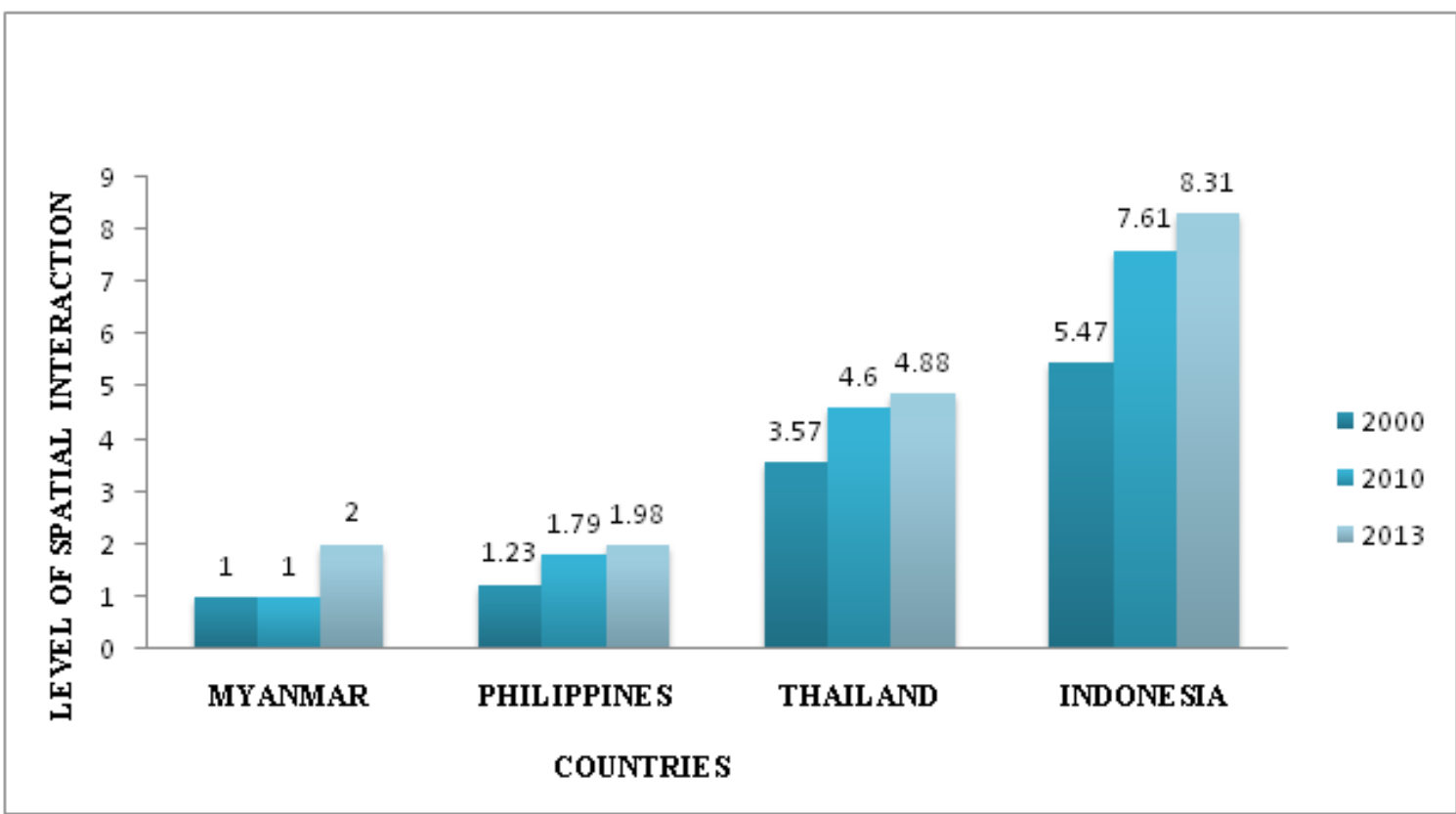

Figure1: Level of Spatial interaction of neighbor counties with Malaysia, 2000-2013

But the actual proportion of labour flow from different countries to Malaysia is differing from predicted value of the gravity model. The Figure 2 shows the actual proportion contributed by the different countries in Malaysia from selected time periods. The gravity model which shows that Myanmar and Philippines, these countries supposed to have lower level of migration with the Malaysia but these countries contribution in labour migration is way much higher. The contribution of Thailand in labour sending in Malaysia is much lower than the predicted value of gravity model. Thailand contributes to only $0.3 \%$ migrant labour in Malaysia in 2000, $0.94 \%$ in $2010 \& 0.75 \%$ in 2013.Though Philippine which has less geographical proximity has much higher contribution in labour sending in Malaysia than Thailand. The same case can be seen for Myanmar. If we see the share of the Indonesia in the contribution of labour migration, it is the single dominant origin country of migrant workers migration in Malaysia.

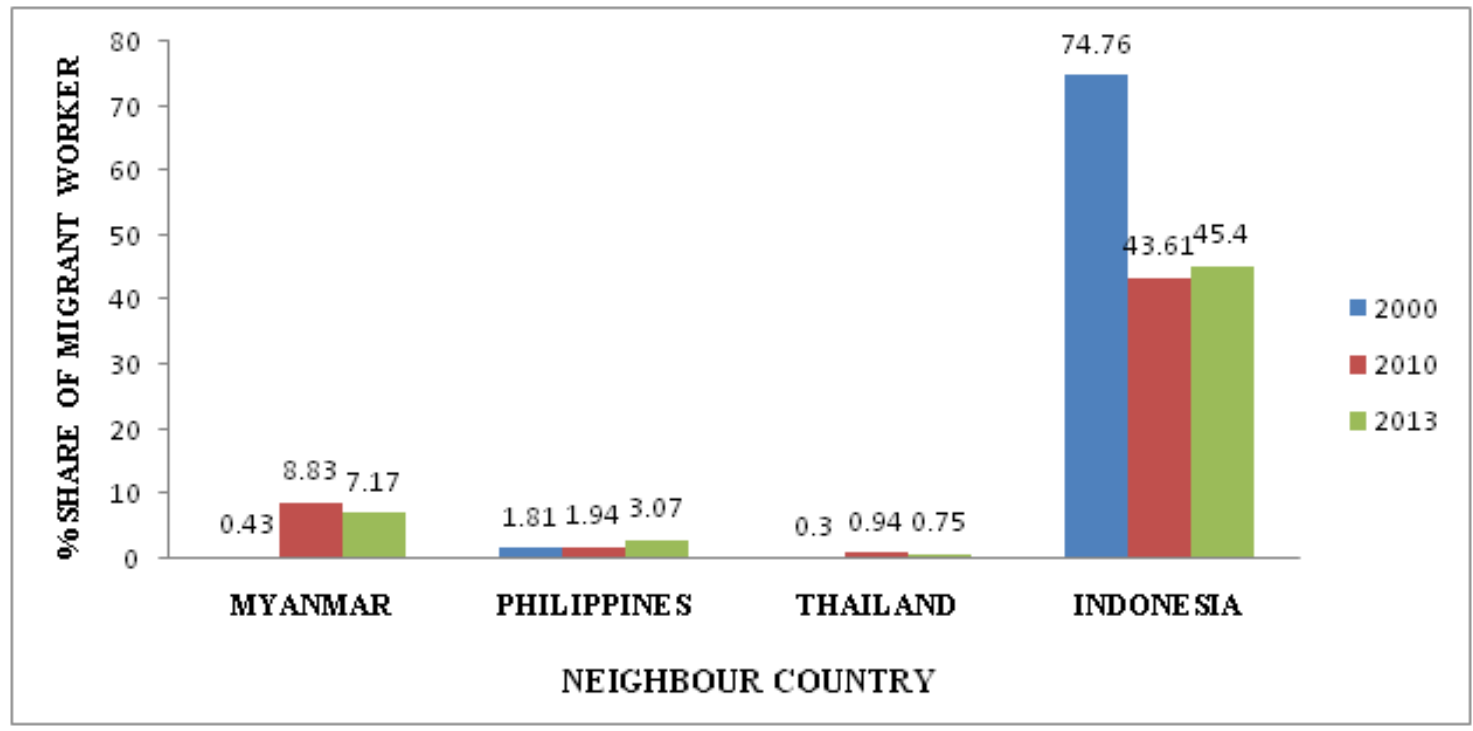

Figure2: Actual proportion of labour contributed by neighbor counties in Malaysia, 2000-2013

\subsection{Analysis of Trend of the Concentration of Migrant Workers in Different Sectors in Malaysia}

In 2014, 1.8 million migrant workers represented total 13\% labour force in Malaysia. The involvement of migrant workers in different economic sector is not same. Here the sector wise concentration of migrant workers in different sector is analysed (2006-2015). Figure 3 shows the percentage share of the migrant workers in 3 categories - agriculture, industry and service sector. The 
major immigrated workers are involved in the manufacturing sector at share of $37 \%$ followed by the service sector at $35 \%$ and $28 \%$ in the agriculture sector. Within the industry sector $60 \%$ of migrant workers are involved only in manufacturing sub-sector.

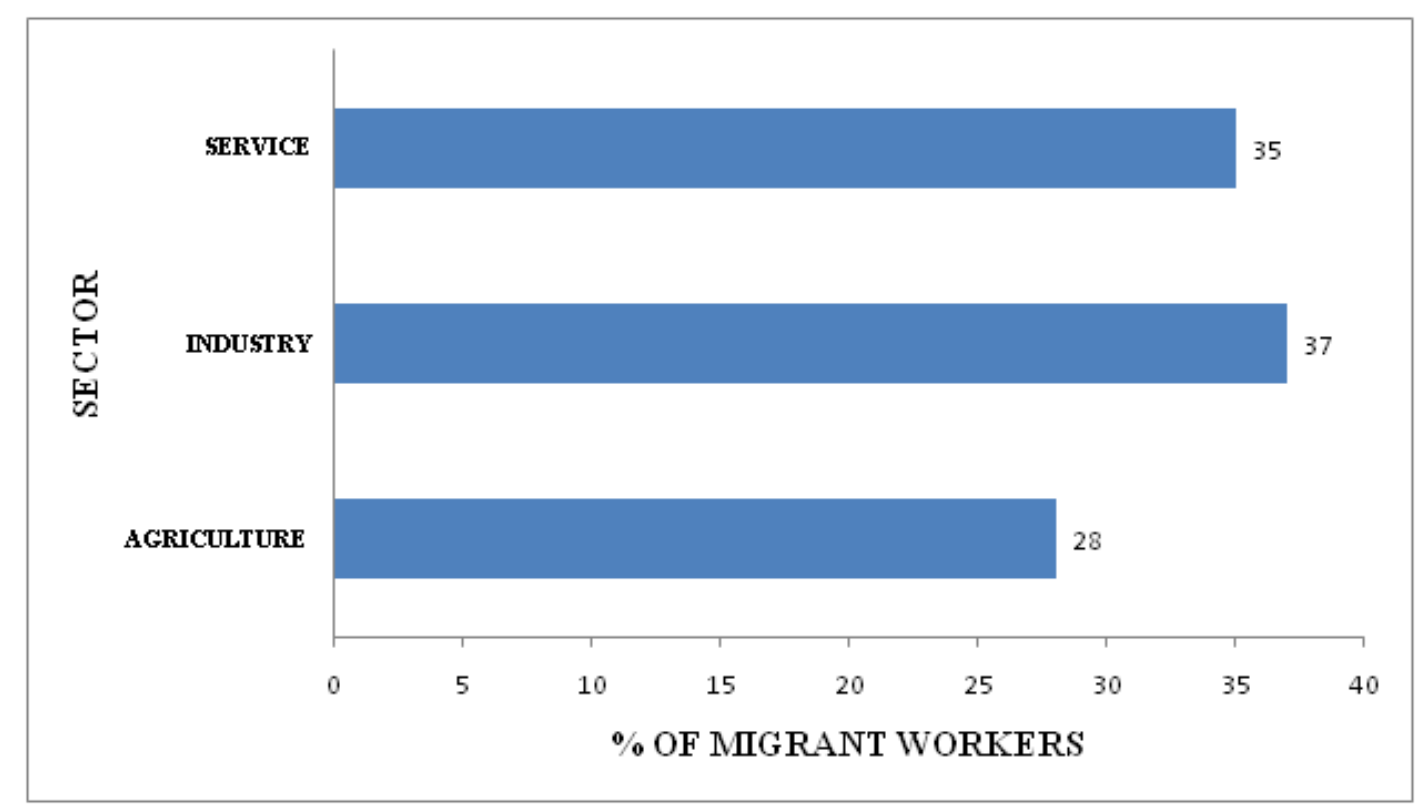

Figure3: Average sectorial share of migrant workers in Malaysia, 2006-15

But the sector wise concentration of migrant workers to total workers is different. Table 1 shows in agriculture sector the concentration of migrant worker is higher than the industry and service sector in Malaysia. The LQ value of migrant worker in agriculture is on average 2 that means migrate workers are much highly involved in agriculture than the average involvement of native workers in agriculture sector in Malaysia. Industry is the second sector in which migrate workers are concentrated higher than the average involvement of workers. On average The LQ value for industry is 1.2. Whereas the involvement of the migrant worker in service sector is lower than the country's average condition.

Table1: Concentration of migrant workers in different sectors in Malaysia, 2006-2015

\begin{tabular}{|l|l|l|l|}
\hline Year & \multicolumn{3}{|c|}{ Worker in different sectors } \\
\hline & \multicolumn{1}{|c|}{ Agricultural Industry } & \multicolumn{1}{c|}{ Service } \\
\hline 2006 & 2.01 & 1.17 & 0.64 \\
\hline 2007 & 2.31 & 1.09 & 0.61 \\
\hline 2008 & 2.44 & 1.12 & 0.59 \\
\hline 2009 & 2.39 & 1.13 & 0.63 \\
\hline 2010 & 2.14 & 1.27 & 0.6 \\
\hline 2011 & 1.92 & 1.44 & 0.6 \\
\hline 2012 & 1.66 & 1.4 & 0.66 \\
\hline 2013 & 1.62 & 1.47 & 0.63 \\
\hline 2014 & 2.16 & 1.31 & 0.62 \\
\hline 2015 & 2.44 & 1.31 & 0.56 \\
\hline
\end{tabular}

Source: International Labour Migration Statistics Database in ASEAN June (2016)

\section{DISCUSSION}

The study shows that the level of interaction in term of individual movement supposed to be low for country like Myanmar; Philippines as per gravity model and with Thailand the level of interaction in term of individual movement supposed to be high but in actual Myanmar and Philippines contributes labour higher than Thailand. Thailand contributes to only $0.3 \%$ migrant labour in Malaysia in 2000, $0.94 \%$ in $2010 \& 0.75 \%$ in 2013. Though Philippine which has less geographical proximity has much higher contribution in labour sending in Malaysia than Thailand. The same case can be seen for Myanmar. If we see the share of the migrant labour from Indonesia, it is the single dominant origin country of migrant workers in Malaysia. In spatial interaction-geographical proximity has some role to play in labour migration in Malaysia. For example Indonesia is one of the examples but only absolute distance can't determinate the intensity of labour migration in present scenario. The policies, 
economic situation, demographic change, globalization etc. influence the immigration patter in labour in Malaysia [3]. From existing literature it can be state that the immigration of labour from Thailand may be low because in the Thailand unemployment has been recorded very low at 0.7 percent annually, slowing work force growth, low demographic growth rate, aging population etc. leads to their own demand for the labour[4]. Existing literature says "Philippine overseas migration has become a pair of crutches for the local economy, serving two main objectives - to ease the unemployment situation and to generate foreign incomes to fuel the faltering economy" [5]. In case of Myanmar, Malaysia is 2nd largest receiving country of Burmese population. More than 250,000 Burmese workers are there in Malaysia in 2015 [6]. The existing study shows unemployment, lack of economic opportunity, rural poverty is the key driver of international labour movement in Myanmar. The concentrations of the migrant workers are in agriculture and industrial sector. Only $10 \%$ and $23 \%$ native workers of Malaysia are in agriculture and industry sector creating huge demand for labour force leading high concentration of migrant worker in these sectors.

\section{CONClusion}

No doubt for Malaysia, its geographic location plays role in the labour inflow neighbor countries .For example Indonesia is the best example as it is geographically proximity to Malaysia. In other hand, Philippines or Myanmar which has comparably low geographical proximity should have low spatial interaction, still the high contributing origin country of labour force in Malaysia. That indicates for different country the spatial interaction or geographical proximity don't play role in labour migration in Malaysia. Geographical proximity is important factor for labour migration but policy, economic condition of the origin country directly influence the labour migration. This is clear from Malaysia. As Myanmar or Philippines economic condition is less developed so high inflow of worker from these countries to Malaysia takes place. Immigrate workers are involve mainly in industrial sector and agricultural sector due to low involvement of native workers. Native Malaysian workers are mainly service sector creating a vacuum for the agricultural and industrial sector and that has supplemented by the migrant workers.

\section{LIMITATION}

The work based on ILO data only talk about the registered, legal migration, the paper doesn't deal with irregular migrant in Malaysia which is one of important aspect there.

The study only talk about the geographical proximity and spatial interaction, how it influence the immigration of labour in Malaysia but the temporal variation in the labour immigration from neighbor countries, it's reason has not been investigated. Much work is needed to be done on that aspect.

\section{REFERENCE}

[1] (2008) Situation Report on International Migration in East and South-East Asia. BANKOK: International Organization for Migration, Regional Office for Southeast Asia.

[2] Kaur, A. (2010). Labour migration in Southeast Asia: migration policies, labour expoloitation\& regulation. Journal of the Asia Pacific Economy, 19

[3] (2013). Immigration in Malaysia: Assessment of its Economic Effects, and a Review of the Policy and System. World Bank.

[4] (2015). ILO global estimates on migrant workers: Results and methodology. GENEVA: INTERNATIONAL LABOUR OFFICE

[5] Wickramasekera, P. (2002). Asian Labour Migration: Issues and Challenges in an Era of Globalization. Geneva: INTERNATIONAL LABOUR OFFICE.

[6] Baruah, N. (2016). Review of labour migration policy in Malaysia. Bangkok: International Labour Office.

[7] (2013). Immigration in Malaysia: Assessment of its Economic Effects, and a Review of the Policy and System. World Bank.

[8] Berg, O. “. (2013). The Economics of Immigration Theory \& Policy. Springer, 27-57

[9] Kessler, C. (2009). Democratic Citizenship and Labour Migration in East Asia Mapping Fields of Enquiry. European Journal of East Asian Studies, 181-213.

[10] Lim, L. L. (1996). The Migration Transition in Malaysia. Asian and Pacific Migration Journal.

[11] Rahmah Ismail, F. Y. (2014). Foreign Labour on Malaysian Growth. Journal of Economic Integration, 657-675. 


\section{AUTHORS' BIOGRAPHY}

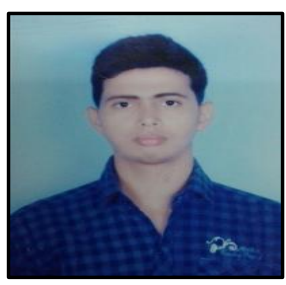

Mr. Babul Hossain, is currently an M.Phil. Student at International Institute for Population Sciences (IIPS) in the department of development studies, Mumbai. He holds a master's in Geography from Jawaharlal Nehru University, New Delhi and second master's in Population Studies from IIPS, Mumbai. His research interest include demography and development, health geography and urban policies focusing health and development, migration issues.

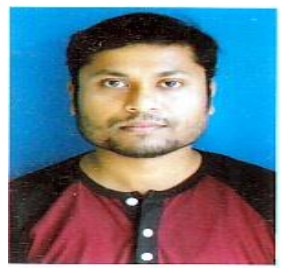

Mr. Saugata Kundu, is currently an assistant teacher at Lakshmipur Michhutola Jr. Basic School, Malda (West Bengal). He holds a masters in Geography from Rabindra Bharati University, Kolkata. His research interest includes Environmental Geography, Geomorphology and Hydrology focusing also on human's behaviour and interference to the natural environment.

Citation: Babul Hossain, Saugata Kundu. "Labour Migration in South East Asia: A Case Study of Malaysia (2000-2015)". International Journal of Research in Geography. vol 5, no. 3, 2019, pp. 7-12. doi: http://dx.doi.org/10.20431/2454-8685.0503002.

Copyright: () 2019 Authors. This is an open-access article distributed under the terms of the Creative Commons Attribution License, which permits unrestricted use, distribution, and reproduction in any medium, provided the original author and source are credited. 